in which progress depends on the co-operation of science and experience". Another German physicist born in 1840 was Friedrich Kohlrausch (1840-1910), the successor of Helmholtz and the predecessor of Warburg, as president of the Reichsanstalt at Charlottenburg. In France 1840 saw the birth of Emile Duclaux (1840-1904), an early assistant to Pasteur, who after his master's death became director of the Pasteur Institute.

Sweden has long been famous for its chemists and metallurgists, and among the former are Lars Fredrik Nilson (1840-99) and Per Theodor Cleve (1840-1905). Both studied at Uppsala, both held chairs there and at Stockholm and both were elected foreign members of the Chemical Society. The memorial lecture to the Society on Nilson was given by Prof. Otto Pettersson and that on Cleve by Sir Edward Thorpe. Speaking of the position Sweden occupied in relation to chemistry, Thorpe said that "when regard is had to her position among continental nations-to her chequered political history, to her geographical isolation, the comparative sparseness of her population, her relative poverty, the fewness of her seats of learning-the influence which Sweden has been able to exert on the development of that branch of science, which it is the proper function of this
Society to foster, must always excite our wonder, admiration and gratitude. The mere mention of the names of Bergmann, Scheele, Berzelius, Mosander, Gadolin, Nilson, is sufficient to remind us how great have been her services to the science of chemistry".

To this necessarily incomplete list of men distinguished in science, invention or engineering may be added the names of the American geologist Edward Drinker Cope (1840-97) ; the AmericanBritish inventor and engineer Sir Hiram Stevens Maxim (1840-1916); the Irish astronomers Lord Rosse (1840-1908) and Sir Robert Stawell Ball (1840-1913); the Scottish inventor John Boyd Dunlop (1840-1921) of pneumatic tyre fame; the English metallurgist James Riley (1840-1910), and the great civil engineer Sir Benjamin Baker (1840-1907), whose name will always be remembered in connexion with the Forth Bridge, the Aswan Dam and other important constructions. Baker was elected F.R.S. in 1890, and served as president of the Institution of Civil Engineers in 1895. He died at Pangbourne on May 19, 1907, and was buried at Idbury, in the Cotswolds. On December 3, 1909, a memorial window to him was unveiled in the north aisle of the nave of Westminster Abbey.

\title{
FOOD FROM GARDENS AND ALLOTMENTS
}

\section{By Sir John RusSEll, F.R.S., Rothamsted EXPERIMENTAL Station}

$\mathrm{T}^{\mathrm{H}}$ HANKS to numerous official inquiries, the quantities of food required by the population of Great Britain are fairly well known. Our diet is both generous and varied. The total food consumption averages rather more than $900 \mathrm{lb}$. a head without counting milk and eggs. Apart from these the per capita consumption falls into five groups : about $200 \mathrm{lb}$. each of (1) wheat, (2) potatoes, (3) other vegetables and fruits, and (4) meat and fish combined; (5) some $140 \mathrm{lb}$. of other foods, chiefly sugar (94 lb.) with smaller quantities of butter ( $25 \mathrm{lb}$.$) , margarine (8 \mathrm{lb}$.$) and$ cheese (10 lb.).

We produce at home all the potatoes, the liquid milk, and much of the vegetables; about half the meat and fish, but only 15 per cent of the wheat and some 10 per cent of butter. We produce rather less than 40 per cent of the total money value of our foods, and rather less than 50 per cent of the total weight. On an average, for each individual there is in peace time an import of about $4 \mathrm{cwt}$. of food per annum.
One of the most urgent problems at the present time is to reduce this figure. It is made up roughly as follows :

$$
\begin{aligned}
& \begin{array}{llllll}
\text { Wheat } \quad . & \ldots & \ldots & 1 \frac{1}{2} & \text { cwt. }
\end{array} \\
& \begin{array}{lllll}
\text { Meat and fish } & \text {.. } & \ldots & 1
\end{array} \\
& \text { Fruit, butter, cheese, etc. .. } 1 \text { ", } \\
& \begin{array}{llllll}
\text { Sugar } & \text {.. } & . & \ldots & 60 & \text { lb. }
\end{array} \\
& \text { Total } \overrightarrow{4} \text { cwt. approximately }
\end{aligned}
$$

The largest item is wheat, of which $170 \mathrm{lb}$. is imported out of the $200 \mathrm{lb}$. consumed. We shall, however, produce more. The plan of the Ministry of Agriculture is to plough up two million acres of land in all ; in the War of 1914-1918, when this was nearly accomplished, we had added 50 per cent to our wheat production.

If we succeed in doing as much this time, we shall reduce the $170 \mathrm{lb}$. of imports to $155 \mathrm{lb}$., but it seems scarcely likely that we can get much below this. Something could be saved by closer milling, but that would only mean less food for our animals and therefore less meat and milk. For one thing we have insufficient land available; 
wheat is one of the least economical of all crops to grow so far as land is concerned, for while I acre of wheat suffices only for 6-7 persons per annum, 1 acre of potatoes suffices for 70-75.

For meat and fish our imports are about $110 \mathrm{lb}$. annually out of a total consumption of practically $4 \mathrm{lb}$. per week per head. Consumption could be cut down by rationing; but in view of the circumstances that our animal population is now larger than it has ever been before, it seems improbable that there will be much shortage during the first year of the War. Even our animals, however, have been living on imported food, though not to the same extent as ourselves; Dr. Wright recently estimated that some 25 per cent of their total food is imported.

The area of land being limited, all increased allocation of land for human food means a reduced area for the growth of food for animals. During the War of 1914-1918 the annual production of milk fell by 400 million gallons, a reduction of 20 per cent, while that of meat fell by 170,000 tons, a reduction of 17 per cent. There were various contributory causes and we shall hope in this War that the fall will not be so great. In seeking to increase production of human food we must not, however, forget our animals.

The import of fruit will be difficult to replace. The Englishman's favourite fruits are bananas, oranges and apples, and two of these must be wholly imported while of the third we produce only a fraction of our total consumption.

Another big item in the import bill is sugar ; the $60 \mathrm{lb}$. of import can be cut down by rationing; we can produce more at home than we are doing and we shall, it is hoped, also make better use of bees. From a reasonably well-kept hive one should obtain some $40 \mathrm{lb}$. of honey, though this is not a net gain because it involves the feeding of some 10-20 lb. of sugar to the bees. On dairy produce we cannot hope to save much. If there were no waste the ration of $\frac{1}{4} \mathrm{lb}$. of butter per week would give us $13 \mathrm{lb}$. a year, not far short of the $16 \mathrm{lb}$. which was our average until recently.

The most hopeful direction of saving shipping is therefore to economize on meat, fruit and sugar, at the same time increasing our home production of wheat and also of animal food so as to avoid the necessity for reducing home production of milk and of meat.

The question to be decided then is : What part can gardens and allotments play in this programme of production?

Experience in the War of 1914-18 shows that production of potatoes can be readily expanded and with great advantage in every way. The production rose in the last war from 7.5 million to 9.4 million tons-an increase of nearly 25 per cent. Potatoes are not only valuable as food for men and for animals; they are also an important source of starch for various other purposes. They are easy to grow and responsive to treatment.

Vegetables will become of increasing importance as the meat ration is cut down ; but unfortunately, while the English gardener can produce them at least as well as anyone else, the English cook usually treats them deplorably. The great difficulty about reducing our meat ration will be that we may be presented with a succession of vegetarian dishes, made dull and tasteless, not through any fault of the vegetables, but because of the incompetence of the cook. For this reason it is very important in any garden or allotment that there should be as wide a variety as possible of vegetables, including particularly those used for salads, and those that can be made up into tasty dishes. Food value is probably of less importance than tastiness ; it seems improbable that our dietary would ever be so seriously curtailed as to be lacking in actual food value; the present danger is that it may lack variety and no longer be appetizing. This the gardener should seek to remedy.

It seems inevitable that sooner or later we must face a reduction in the amount of fruit that we usually import; we can scarcely hope to continue our present supplies of oranges and bananas and imported apples. In many gardens there are fruit trees and bushes in a more or less neglected condition. If these were overhauled they might be made to yield better during the eoming season; the produce may be very welcome, for the deficiency of fruit must somehow be made good both by growing more at home and by using more vegetables.

The increased garden production of potatoes and vegetables would have several important advantages quite apart from ensuring supplies for the grower's table. Farm land now used for the production of potatoes and vegetables could be released for other purposes, especially for the production of fodder crops for animals, thus saving the necessity for uneconomic slaughter and ensuring continued milk and meat production.

Much internal transport could also be saved. At the present time many parts of Great Britain are not self-supporting in potatoes and vegetables, and considerable quantities have to be transported from county to county, occupying valuable truck space or using up petrol on the roads. It would be a great advantage if this internal transport could be cut down.

The possibilities of increase are considerable. It is estimated that there are some $3 \frac{1}{2}$ million gardens and 900,000 allotments in the country. The Ministry of Agriculture is stimulating the formation 
of new allotments, aiming at establishing another 500,000 . Many of the existing gardens and allotments are not, however, fully used, and it is desirable to improve them as speedily as possible. Technical advice is now available in every county. There is, however, a real danger of considerable waste of seed and manure, neither of which can well be spared now. Here there seems a useful opening for local distribution that could ensure distribution of manure and interchange of seedlings . 80 as to avoid the present wasteful methods. Distribution of excess produce is another important problem, for however well the garden is planned it is impossible to avoid an excess at one period and a deficiency at another. Unfortunately, organization of garden production is peculiarly difficult and in the past has rarely succeeded, but that is no reason why it should not again be attempted, as in the last war. Finally comes the important question of utilization of garden wastes ; the best way, the keeping of pigs and poultry, is not usually possible. In any event, even if these are kept, the compost heap is an essential part of a good gardener's equipment.

\section{THE EARTHQUAKE IN TURKEY}

\section{By E. Tillotson}

$\mathrm{T}$ HE greatest earthquake ever recorded in Turkey, and probably the greatest natural catastrophe which Turkey has ever suffered, occurred on December 27, when, between approximately 1.57 a.m. and 5 a.m. local time (East European), there were at least seven terrific earthquake shocks. These shocks caused havoc on and near the Black Sea coast of Anatolia in northeastern Turkey, where, to the accompaniment of underground rumbling, upwards of fifteen towns having populations of between fifteen and forty thousand persons each, together with more than ninety villages, were practically razed to the ground, communications by telegraph, road and rail destroyed, and estimated casualties of 45,000 killed and 20,000 wounded caused.

The first news of the catastrophe was received from the Bendandi Observatory at Faenza, which reported that an earthquake of catastrophic dimensions was registered on its seismographs at 1 a.m. (Mid-European time). The earthquake was estimated to have taken place in Armenia, and the vibration at Faenza was so intense that the recording instruments were damaged. Similar news came from the Swiss observatories, and at Zurich the shock was received at 1.2 a.m. (MidEuropean time). The seismograph belonging to Mr. J. J. Shaw at West Bromwich was also damaged by the earthquake, though Mr. Shaw was away from home at the time. Shortly after the news from Faenza, messages were received from Ankara stating that earthquake shocks had been experienced there.

The full force of the principal shock was felt at Erzinjan, a town situated at an altitude of $4000 \mathrm{ft}$. above sea-level where a brisk trade was conducted in silks, cotton and copper. The town was immediately reduced to a heap of ruins and about 80 per cent of the population killed. The upsetting of oil lamps and stoves and the breaking of gas pipes caused hundreds of fires to break out in all parts of the town, which the surviving brigades could not extinguish on account of broken pipe lines and huge eracks in the roads. Telephone and telegraph communications were also disrupted. Here, included in the wreckage, were the military barracks and club and military school, where ten officers and ninety cadets are known to have lost their lives, though a much greater military death roll is feared. Damage only a little less severe was done at many other towns. Sivas, a town of 65,000 inhabitants, the centre of caravan routes and a collecting place for the agricultural produce grown in the surrounding districts, together with Tokat in Sivas Province, a town of 31,000 inhabitants engaged largely in calico manufacture, and the intervening villages, were practically wholly destroyed. Many people, in bed at the time of the first shock, were buried alive in the wreckage of their homes. The district of Kemah, the town of Yozgat and the town of Amasya, with a population of 30,000 , in the midst of fruit-growing country, are all in ruins. At Samsun in the Trebizond district, a seaport with a population of 15,000, exporting copper, timber, tobacco, wool and other agricultural products, mosques, minarets, schools and public buildings-some of them built of reinforced concrete-and private houses came crashing down, killing thousands of people. Ordu, in the tobacco-growing district, suffered similarly, as did also Giresun, Malatya, Turhal, Gumushane, Refahive and Plumer. On the night of December 28 fires were still blazing amidst the ruined buildings, and to add to the difficulties of the rescue parties a blizzard was raging in the countryside at a temperature of $2^{\circ} \mathrm{F}$. Of the 350 inhabitants of 